\title{
The effect of fish stocking on mountain lake plankton communities identified using palaeobiological analyses of bottom sediment cores
}

\author{
Elwira Sienkiewicz (D) Michał Gąsiorowski
}

Received: 25 February 2015/Accepted: 19 December 2015/Published online: 24 December 2015

(C) The Author(s) 2015. This article is published with open access at Springerlink.com

\begin{abstract}
The artificial introduction of fish into a naturally fishless lake can effectively modify the food web and trophic status of that lake. We observed changes in the zooplankton community after stocking fish in Przedni Staw Polski, an oligotrophic mountain lake in the Tatra Mountains (Poland). Results were compared with observations about a stocked lake that naturally contained fish (Morskie Oko), and with two fishless lakes that served as reference sites. The main change observed in the cladoceran community of Przedni Staw Polski was the elimination of largebodied Daphnia $\sim 10$ years after stocking fish. The introduction of fish also affected the phytoplankton community and resulted in an increase in diatom species related to higher trophic state, most likely due to the fish-induced alteration of the phosphorus cycle. Moreover, all of the studied lakes have been influenced by global and regional climatic and environmental changes, including intensive tourism and acid deposition. Changes in diatom communities were observed after fish stocking even in the lake with a natural fish population, while the zooplankton did not reflect higher fish density. These findings suggest that
\end{abstract}

E. Sienkiewicz $(\bowtie) \cdot$ M. Gąsiorowski

Institute of Geological Sciences, Polish Academy of

Sciences, Research Centre at Warsaw, St. Twarda 51/55,

00818 Warsaw, Poland

e-mail: esienkie@twarda.pan.pl

M. Gąsiorowski

e-mail:mgasior@twarda.pan.pl the natural balance between fish and phytoplankton was destroyed by fish stocking, and although it caused eutrophication in the lake, the higher fish density did not strongly modify the species composition of Cladocera.

Keywords Fish stocking - Diatom - Cladocera · Trophic changes $\cdot$ Mountain lakes $\cdot$ Fishless lakes

\section{Introduction}

Fish are a very important element of the food web of a lake. According to the top-down hypothesis, as top predators, fish can control the trophic state of a lake (Carpenter and Kitchell 1993). By selective predation on large-bodied zooplankton, planktivorous fish can effectively eliminate phytoplankton grazers and indirectly induce phytoplankton blooms. In addition, fish can also control the density of invertebrate predators, thereby promoting the development of small-bodied zooplankton (Tolotti 2001).

Hence, when fish are introduced to an oligotrophic, naturally fishless lake, it can quickly restructure the food web by effectively eliminating large-bodied cladocerans and copepods (Tiberti et al. 2014). Fish stocking also indirectly causes an increase in nutrient contents and algal biomass (Carpenter et al. 1995). A change occurs in the nutrient cycles supporting the growth of primary production by the assimilation and internal loading of phosphorus from the sediments, 
which is normally not available to pelagic communities in oligotrophic lakes (Jacques et al. 2005). Phosphorus is one of the factors responsible for eutrophication of fresh water ecosystems (Katsaounos et al. 2007). An increase in total phosphorus above $10 \mu \mathrm{g} \mathrm{L}^{-1}$ in the water of an oligotrophic lake leads to an alteration towards eutrophication. In lake sediment, phosphorus occurs as inorganic and organic compounds. Inorganic phosphorus is bioavailable mainly in the dissolved form. Benthivorous fish have clear influence on the phosphorus concentration in lake water and on the resuspension of sediments (Sønderaard et al. 2003). Bottom-feeding fish often stir up bottom sediments, which can release internal phosphorous accumulated in sediments into the lake water, a bottom-up process. As a consequence, a higher nutrient load accumulates, which is available to phytoplankton and leads to increased algal production under conditions of reduced grazing by zooplankton (Schindler et al. 2001; Wolfe et al. 2003). On the other hand, the presence of benthic fish can increase turbidity and reduce the light needed for photosynthesis (Roozen et al. 2007). Phosphorus release is controlled by many processes, which can be physical (e.g., resuspension, temperature), chemical (e.g., $\mathrm{pH}$, redox state) or biological (e.g., bioturbation, submerged macrophytes) (Temporetti and Pedrozo 2000).

The first known successful fish stocking in the Tatra Mountain lakes occurred in the second half of the nineteenth century (Gliwicz and Rowan 1984). In some of these lakes (e.g., the Przedni Staw Polski, Czarny Staw Polski, Zielony Staw Gąsienicowy and Litworowy Staw Gąsienicowy) salmonids have acclimatised. However, fish introduction was not successful in other lakes due to limited food availability, low water temperature, and a long ice-cover period. Assessment of the effect of fish introduction on primary fishless lakes in the Tatra Mountains cannot be based solely on the direct interpretation of the subfossil record. Despite their remote location, the lakes in the Tatra Mountains have been affected by global and regional climatic and environmental changes, including intensive tourism and acid deposition (Gąsiorowski and Sienkiewicz 2013; Sienkiewicz and Gąsiorowski 2014). These global and regional effects have interfered with the local impact of fish stocking.

We assumed that fish stocking would strongly impact the phyto- and zooplankton of oligotrophic alpine lakes. Because plankton communities in naturally fishless lakes are different from those in lakes where the food web is controlled by fish predation, we expected a large change in species composition and density related to fish stocking episodes. Such a conclusion was published by Strock et al. (2013) concerning the introduction of white perch into oligotrophic lakes in the eastern United States.

To test our hypothesis, we studied changes in the subfossil plankton records of two lakes with fish populations in the Tatra Mountains: one lake had a natural population of brown trout; the other lake was naturally fishless, but brook trout were introduced in the mid-twentieth century. Moreover, we studied two nearby and naturally fishless lakes as reference sites. Shifts in the biota were also correlated with isotopic $\left(\delta^{13} \mathrm{C}, \delta^{15} \mathrm{~N}\right)$ and elemental analyses of organic carbon and nitrogen ( $\mathrm{C} / \mathrm{N}$ and TOC), and the magnitude of lake primary production was also determined. As an indicator of phosphorous concentration, we used a reconstruction based on changes in diatom species composition (DI-TP). This also helped to determine the trophic level before and after the introduction of fish to the lakes. Changes in lake organic matter could be a result of processes occurring in situ from plankton and benthic sources. In addition, terrestrial biomass, soil and lithic fragments transported from the catchment area could also be possible sources of nutrients.

\section{Study sites}

Morskie Oko (MOK) in the Rybi Potok Valley (Fig. 1) is the only lake in the Polish part of the Tatra Mountains with a natural population of fish (brown trout, Salmo trutta m. fario L.). Impassable obstacles in the form of high cascades (Pięć Stawów Polskich Valley) and streams that run dry upon ending underground in a system of caves (Gąsienicowa Valley) prevent the fish from reaching other lakes. The survival of fish in Morskie Oko is probably also associated with the lake being located below the tree line and under milder climate conditions (a relatively short ice-covered period) compared to lakes situated at higher altitudes in the Tatra Mountains. In 1881, Morskie Oko was additionally stocked with 1850 specimens of Salmo trutta m. lacustris and non-native brook trout, (Salvelinus fontinalis (Mitchell), originating from North America (Witkowski 1996). These species were also introduced to other lakes in the 


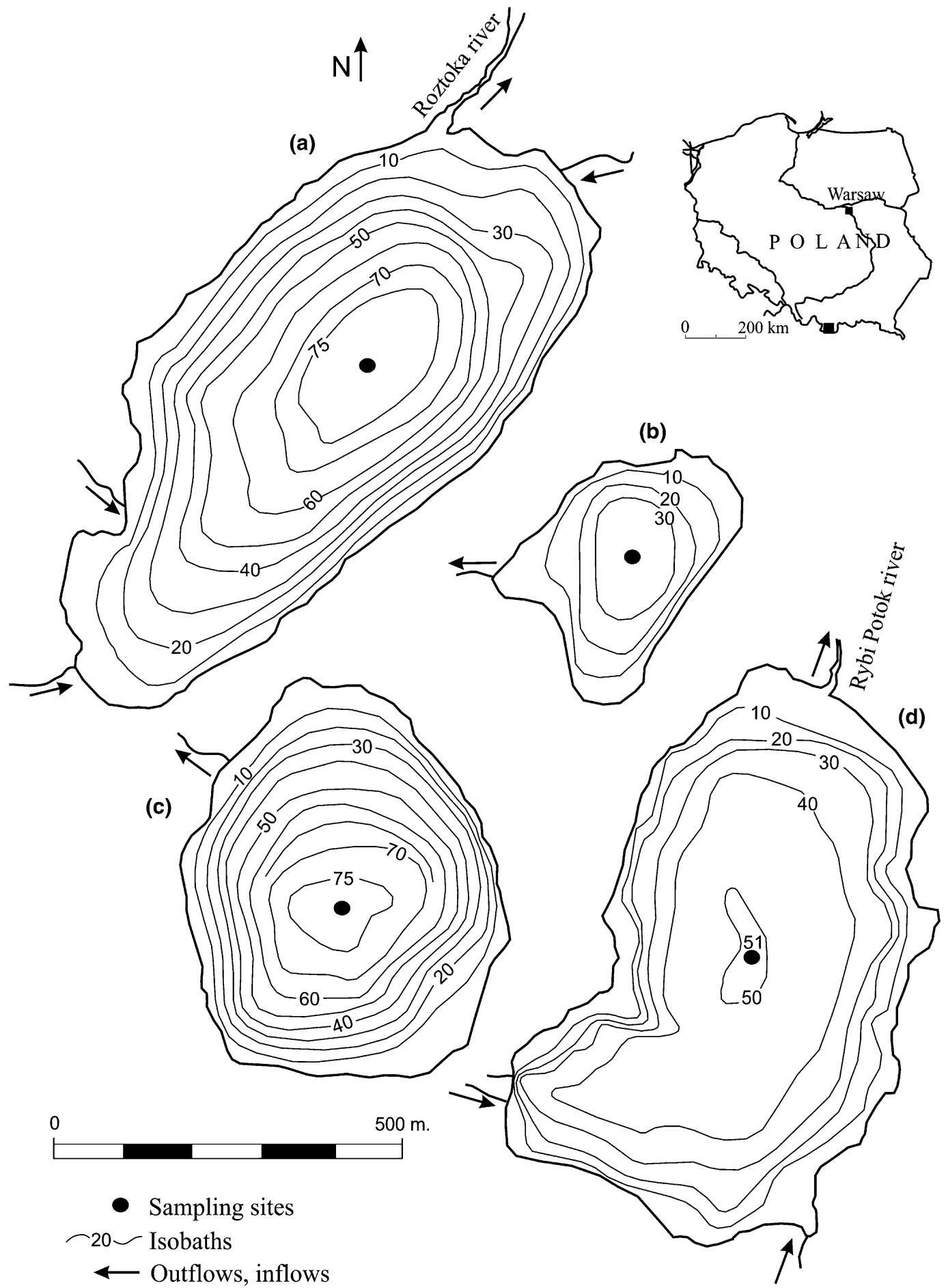

Fig. 1 Location and bathymetric maps of Wielki Staw Polski (a) and Przedni Staw Polski (b) in the Pięć Stawów Polskich Valley and Czarny Staw pod Rysami (c) and Morskie Oko (d) in the Rybi Potok Valley 
region, and in some of these lakes, this introduction caused changes in the plankton communities. Selective predation was a direct impact of the fish on zooplankton (Gliwicz and Rowan 1984; Ślusarczyk 1997), but the fish also caused changes in the transparency and chemical composition of the lake water (Hořická et al. 2006). For example, brook trout were likely responsible for the extinction in Morskie Oko of the fairy shrimp Branchinecta paludosa O. F. Müller, a Pleistocene relic that presently occurs in Poland only in Dwoisty Staw Gąsienicowy in the Tatra Mountains (Kownacki 2004). Czarny Staw pod Rysami (CSR) is a naturally fishless lake situated in the same valley as MOK. The cirque that contains the lake is surrounded by steep walls (up to $600 \mathrm{~m}$ high), which shade the lake surface. Even during warm summers, relatively low temperatures are observed in Czarny Staw pod Rysami compared with other lakes located at a similar altitude (Makos et al. 2012). Since 1883, several attempts have been made to stock the lake, but harsh climatic conditions and a lack of food inhibited the establishment of the fish.

The lack of fish in Czarny Staw pod Rysami permitted the development of an extraordinary population of large-bodied Daphnia pulicaria that coexisted with abundant Cyclops (Gliwicz et al. 2001). In contrast, fish predation pressure in Morskie Oko caused the disappearance of large-bodied zooplankton and domination by small-bodied D. longispina and Bosmina longirostris (Ślusarczyk 1997).

Wielki Staw Polski (WSP) and Przedni Staw Polski (PSP) are located close to each other in the Pięć Stawów Polskich Valley. WSP is fishless, while PSP was stocked with brown and brook trout in 1949 and in the 1960 and 1970s (this last event was the greatest of these stockings; Gliwicz and Rowan 1984). It is possible that some fish from Przedni Staw Polski can reach Wielki Staw Polski during high water stands because PSP is situated several metres higher than WSP. Both lakes are located above the timberline, and their catchments are characterised by rocks and alpine meadows (Stuchík et al. 2006). The morphometric and chemical parameters of all studied lakes are summarised in Table 1.

\section{Materials and methods}

Sediment cores were collected from the deepest part of the studied lakes using a Kajak-type gravity sediment corer (Fig. 1). The cored sediments from the MOK, CSR, PSP and WSP lakes were divided every $1 \mathrm{~cm}$. Sediments younger than 150 years were dated using a ${ }^{210} \mathrm{~Pb}$ method at the Institute of Geological Sciences P.A.S. in Warsaw. The lead-210 dating followed the method previously applied by Gąsiorowski and Sienkiewicz (2010) and tested by Hercman et al. (2014). We measured lead-210 activity indirectly by alpha-spectrometry counting ${ }^{210}$ Po activity. The Constant Rate of Supply (CRS) model was then applied for age calculations. The older sediments were radiocarbon dated in the Radiocarbon Laboratory in Poznań (Poland) with an accelerator mass spectrometer (Goslar and Pazdur 1989). Conventional radiocarbon dates were calibrated with OxCal software (Bronk Ramsey 2009) using an IntCal13 calibration curve (Reimer et al. 2013) (Table 2). Finally, MOD-AGE software was applied (Hercman and Pawlak 2012) and age-depth models combining lead and radiocarbon (if applicable) dates were calculated using a randomisation method and the age-depth functions were fitted using the LOESS algorithm.

For the elemental $(\mathrm{C} / \mathrm{N}$ ratios and TOC concentration) and stable isotopic $\left(\delta^{13} \mathrm{C}\right.$ and $\left.\delta^{15} \mathrm{~N}\right)$ analyses, samples were pre-treated with $5 \% \mathrm{HCl}$ to remove carbonates, then washed with distilled water. Next the samples were dried at $105{ }^{\circ} \mathrm{C}$ and ground in an agate mortar. They were then wrapped in tin capsules and combusted at $1020{ }^{\circ} \mathrm{C}$. Released gases $\left(\mathrm{CO}_{2}\right.$ and $\left.\mathrm{N}_{2}\right)$ split in a GC column were transferred to a MS source through a capillary. Stable isotopic composition was determined using a Thermo Flash EA 1112 HT elemental analyser connected to a Thermo Delta V Advantage isotope ratio mass spectrometer in a continuous flow system calibrated using an internal nicotinamide standard. These analyses were performed in the Stable Isotope Laboratory of the Institute of Geological Sciences of the Polish Academy of Sciences in Warsaw.

Diatom samples were prepared for analysis according to a standard procedure (Battarbee 1986). Permanent slides (sample volumes of $1 \mathrm{~cm}^{3}$ ) were created with $\operatorname{Naphrax}^{\circledR}(\mathrm{RI}=1.75)$. At least 300 diatom valves were identified from each slide using an Olympus BX51 light microscope with a $100 \times$ oil immersion objective. The diatoms were identified using Krammer and Lange-Bertalot (1986, 1988, 1991b) and Lange-Bertalot and Metzeltin (1996). AlgaeBase (www.algaebase.org) was used for the more recent nomenclature of diatoms. 
Table 1 Morphometric and chemical characterization of the studied lakes

\begin{tabular}{|c|c|c|c|c|}
\hline & CSR & MOK & WSP & PSP \\
\hline Latitude & $49^{\circ} 11^{\prime} 20^{\prime \prime} \mathrm{N}$ & $49^{\circ} 11^{\prime} 49^{\prime \prime} \mathrm{N}$ & $49^{\circ} 12^{\prime} 33^{\prime \prime} \mathrm{N}$ & $49^{\circ} 12^{\prime} 45^{\prime \prime} \mathrm{N}$ \\
\hline Longitude & $20^{\circ} 04^{\prime} 37^{\prime \prime} \mathrm{E}$ & $20^{\circ} 04^{\prime} 14^{\prime \prime} \mathrm{E}$ & $20^{\circ} 02^{\prime} 27^{\prime \prime} \mathrm{E}$ & $20^{\circ} 02^{\prime} 58^{\prime \prime} \mathrm{E}$ \\
\hline Altitude (m a.s.l) & 1583 & 1395 & 1665 & 1668 \\
\hline Area (ha) & 20.64 & 34.93 & 34.14 & 17.94 \\
\hline Catchment area (ha) & 179 & 630 & 491 & \\
\hline Max depth (m) & 76.4 & 50.8 & 79.3 & 34.6 \\
\hline Volume $\left(\mathrm{m}^{3}\right)$ & $7,761,700$ & $9,935,000$ & $12,967,000$ & $1,130,000$ \\
\hline $\mathrm{Ph}^{\mathrm{a}}$ & 7.14 & 7.13 & 7.03 & 7.23 \\
\hline $\operatorname{ANC}(\mu \mathrm{mol} / \mathrm{L})^{\mathrm{a}}$ & 159.0 & 145.0 & 84.0 & 245.0 \\
\hline $\mathrm{TP}(\mu \mathrm{mol} / \mathrm{L})^{\mathrm{a}}$ & 0.065 & 0.087 & 0.106 & 0.158 \\
\hline $\mathrm{TP}(\mu \mathrm{g} / \mathrm{L})^{\mathrm{b}}$ & 6.18 & 8.27 & 10.07 & 15.01 \\
\hline $\mathrm{TON}(\mu \mathrm{mol} / \mathrm{L})^{\mathrm{a}}$ & 5.8 & 9.2 & 8.1 & 10.8 \\
\hline Chlorophyll-a $(\mu \mathrm{g} / \mathrm{L})^{\mathrm{a}}$ & 0.7 & 1.2 & 0.9 & 8.4 \\
\hline $\begin{array}{l}\text { Anthropogenic fish stocking (name of } \\
\text { fish and year of introduction) }\end{array}$ & - & $\begin{array}{l}\text { Salvelinus fontinalis: } \\
1881\end{array}$ & - & $\begin{array}{l}\text { Salvelinus fontinalis: } \\
1949,1965,1970\end{array}$ \\
\hline Natural fish population & - & Salmo trutta m. fario & - & - \\
\hline
\end{tabular}

a After Kopáček et al. (2006)

b Calculating according to the molybdate method, ANC acid neutralising capacity, TP total phosphorus, TON total organic carbon

Reconstruction of the total phosphorus (DI-TP) was performed using the European Diatom Database (EDDI) and the ERNIE software, version 1.0 (Juggins 2001). A model based on an inverse regression had almost the same RMSEP, but higher $r^{2}$ and maximum bias compared to a classical deshrinking of the locally weighted averaging (LWWA). However, according to Birks et al. (1990) because the reconstructed values lie toward the end of the gradient sampled in the training set, we used classical deshrinking. Using the LWWA method, we obtained a "local" training set for every fossil sample based on the 50 closest analogues defined by the minimum squared Chi squared distance.

The cladoceran samples were prepared for analysis according to Szeroczyńska and Sarmaja-Korjonen (2007). For each sample, $1 \mathrm{~cm}^{3}$ of wet sediment was heated on a hot plate and stirred in $10 \% \mathrm{KOH}$ for $20 \mathrm{~min}$, sieved through a $33-\mu \mathrm{m}$ mesh and dissolved in $10 \mathrm{~cm}^{3}$ of distilled water. A slide was prepared from $0.1 \mathrm{ml}$ of each sample and examined under a light microscope at magnifications of $100 \times$ and $200 \times$ to count the number of cladoceran remains. Two to five slides were scanned from most of the samples. The total number of counted remains in most of the samples was more than 200 (headshields, shells, ephippia and postabdomens). The most abundant body part was chosen for each species to represent the number of individuals, and the percentages were calculated from the sum of the individuals. The percentages of chydorid and bosminid ephippia were calculated in relation to all individuals of the Chydoridae or Bosminidae, respectively, according to Sarmaja-Korjonen (2003). The cladoceran remains were identified using keys by Flössner (2000), and the nomenclature follows that proposed by Szeroczyńska and Sarmaja-Korjonen (2007). The cladoceran local zones were defined on the basis of a ConsLink analysis (Gordon and Birks 1972). The diatom and cladoceran assemblage zones were defined using ZONE software, version 1.2 (Juggins 1992). The significance of zones was validated with one-way analysis of similarity (ANOSIM), which used the Euclidean distance (Clarke 1993). We also used ANOSIM to evaluate an effect of fish introduction to the lakes. Similarity analysis was performed using the software PAST 3.10 (Hammer et al. 2001).

Principal Component Analysis (PCA) was performed on the diatom and Cladocera remains in order to identify the major patterns of variation in the phytoand zooplankton stratigraphical sequences. These analyses were done with CANOCO software version 5 (ter Braak and Šmilauer 2002). This linear regression 


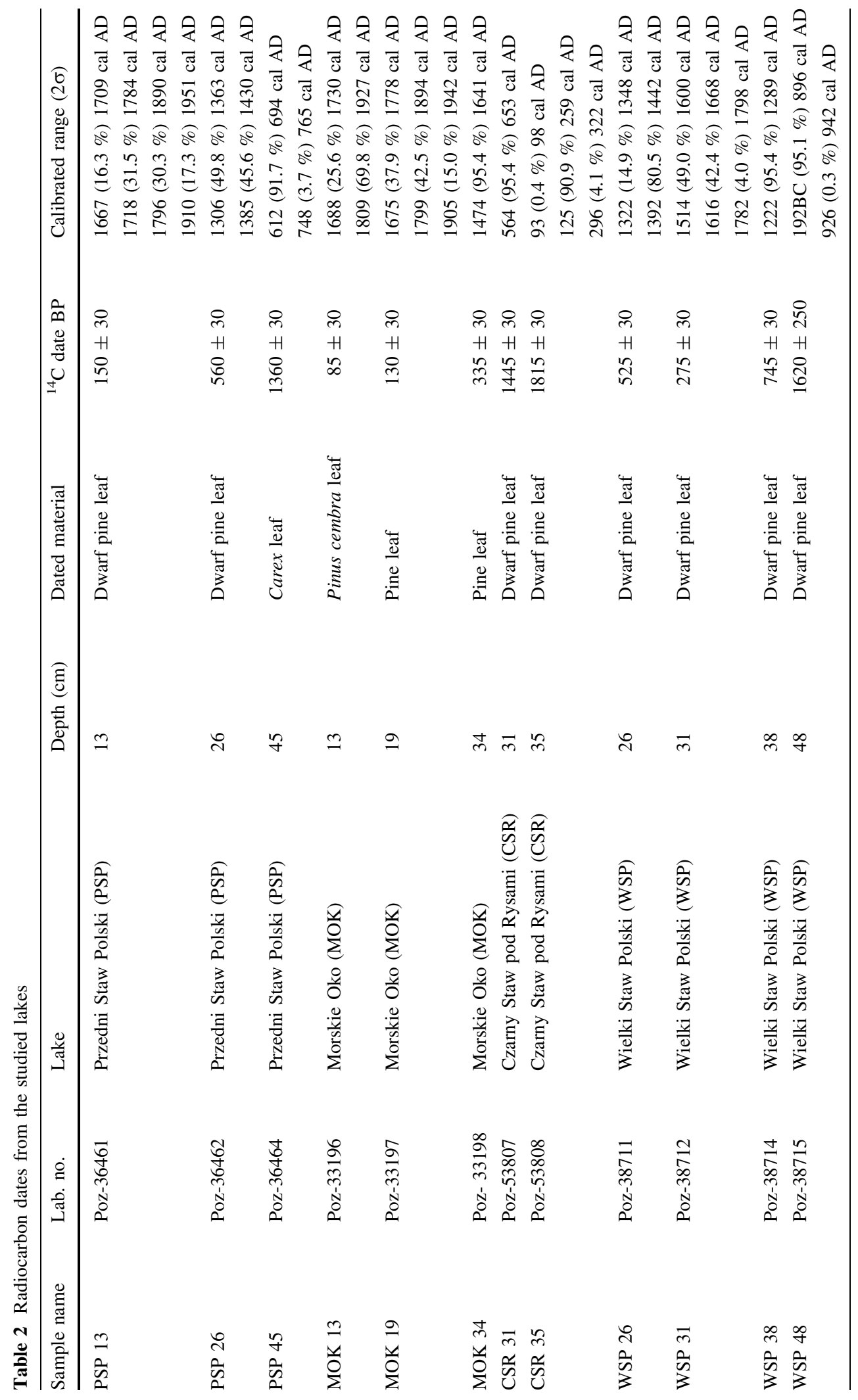


technique was chosen due to detrended correspondence analysis (DCA) indicated relatively short gradient lengths of biological communities for each stratigraphic core (0.64-2.09 standard deviation units). Species of diatoms and Cladocera are represented by the arrows on ordination graphs. The smaller angle between the arrows indicates a high positive correlation of two species. The arrows being in the opposite direction point to high negative correlation, but arrows crossing at $90^{\circ}$ are uncorrelated. Longer arrows are more important in the analysis. Black points represent the sediment samples accumulated in different time. The shorter distances between points indicate more similarity between samples.

\section{Results}

The results of the diatom, cladoceran, isotopic data and quantitative analyses from the sediments of the studied lakes encompassing the last 200 years for Morskie Oko and Przedni Staw Polski were compared to those for Czarny Staw pod Rysami and Wielki Staw Polski.

\section{Chronology and sedimentation rate}

The results of sediment datings were presented and discussed in Hercman et al. (2014) and Sienkiewicz and Gąsiorowski (2014). The age-depth models for studied sediment sequences are presented in Fig. 2. The lowest mean sedimentation rate was calculated for PSP and the highest for MOK core. Sedimentation rate was stable in WSP for the last 200 years, but changed in other lakes. In PSP and CRS sedimentation rate accelerated in the last century. In MOK we recognize several events of faster deposition of sediments.

Diatom and cladoceran stratigraphy, isotopic data and quantitative analyses in the sediments of Morskie Oko (MOK) and Przedni Staw Polski (PSP)

Altogether, 146 diatom taxa belonging to 38 genera were identified in the sediments of Morskie Oko (Fig. 3). The lack of a main dominant species was noted in zone DMOK 1. Diatoms such as Achnanthes sensu lato and Fragilaria nanana Lange-Bertalot occurred at low percentage frequencies. Changes in

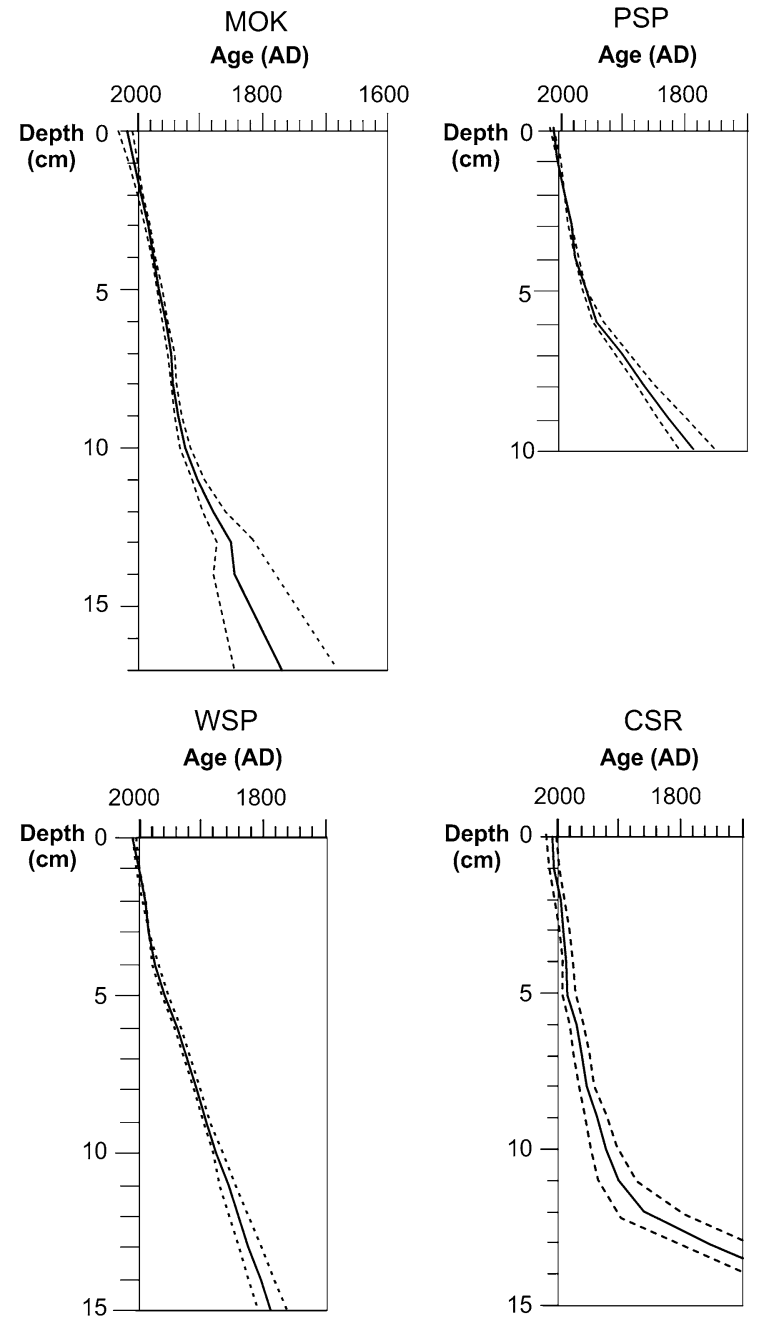

Fig. 2 Age-depth models (solid lines) and their confidence bands (dashed lines) of the studied sediment sequences. Agedepth function for Morskie Oko (MOK) and Przedni Staw Polski (PSP) according to Sienkiewicz and Gąsiorowski (2014)

diatom structure occurred after 1860 (DMOK 2), (Table 3). Prior to this time benthic taxa dominated in the lake. Subsequently, planktonic Aulacoseira subarctica (Müll.) Haworth and Fragilaria nanana increased their frequency, which caused a shift in the ratio between planktonic and benthic taxa, and this was coincident with restocking of the lake. From 1860 to the mid-1980s, the PCA diatom sample scores showed only minor alterations, suggesting a relatively stable taxonomic composition. The next prominent changes were noted in the most recent decades. PCA axis 1 exhibits an increase of Aulacoseira subarctica positioned in the top-right-hand corner of the diagram. 
Table 3 The results of one-way analysis of similarity (ANOSIM with Euclidean distance) for zonation and the effect of fish introduction to the lakes

Large $R$ values indicate dissimilarity between zones

\begin{tabular}{|c|c|c|c|c|c|c|c|c|}
\hline & \multicolumn{4}{|c|}{ Zonation } & \multicolumn{4}{|c|}{ Fish introduction } \\
\hline & \multicolumn{2}{|c|}{ Diatom } & \multicolumn{2}{|c|}{ Cladocera } & \multicolumn{2}{|c|}{ Diatom } & \multicolumn{2}{|c|}{ Cladocera } \\
\hline & $R$ & $p$ & $R$ & $p$ & $R$ & $p$ & $R$ & $p$ \\
\hline MOK & 0.915 & 0.0001 & 0.136 & 0.127 & 0.746 & 0.0008 & 0.004 & 0.436 \\
\hline PSP & 1 & 0.008 & 0.386 & 0.026 & 0.861 & 0.005 & 0.386 & 0.024 \\
\hline CSR & 0.849 & 0.002 & 0.009 & 0.397 & - & - & - & - \\
\hline WSP & 0.741 & 0.003 & 0.407 & 0.002 & - & - & - & - \\
\hline
\end{tabular}

An arrow of this species pointing in direction roughly opposite to the benthic taxa, which lie in the bottomleft-hand corner of the diagram (e.g., Psammothidium curtissimum (Carter) Aboal). They indicate the high negative correlation with A. subarctica. Along PCA axis 2 an increase of Fragilaria capucina Desmazières is observed (Figs. 3, 4). Between the late 1980s and 2010 (DMOK 3), Aulacoseira subarctica was still the dominant species, while the numbers of the tychoplanktonic Fragilaria capucina conspicuously increased. During the past 200 years, the diatominferred TP changed in the range of 8.0-24.8 $\mu \mathrm{g} \mathrm{L}^{-1}$ (Fig. 3). Some of samples in the studied cores have no good fit to the modern training set and should be treated with caution. However, the majority of fossil taxa from all studied lake sediments were present in the calibration set. The lowest cross-validation root mean square error of prediction (RMSEP) was the 0.30 log-transformed TP, and the highest coefficient of determination $\left(\mathrm{r}^{2}\right)$ was 0.70 .

Nine taxa of Cladocera belonging to 2 families were identified and counted in the sediments of Morskie Oko (Fig. 3). Planktonic Bosmina spp. dominated over the entire sequence, which was divided into 3 cladoceran assemblage zones (CMOK). The first zone (CMOK 1) is characterized by relatively high percentages of benthic Acroperus harpae and Alona affinis (Fig. 3). Alona quadrangularis was noted only in this zone. The percentages of chydorid ephippia were also relatively high and reached a maximum ( $\sim 50 \%$ of chydorid remains) at $15 \mathrm{~cm}$. Bosmina was represented only by $B$. longirostis, and Bosmina ephippia were relatively numerous (up to $30 \%)$. The shift to the next zone appeared clear as suggested by the PCA diagram (Fig. 4) but was not significant according to ANOSIM test (Table 3). This zone (CMOK2) was characterised by the occurrence of $B$. longispina and a smaller number of Bosmina ephippia. In zone CMOK3, the percentages of chydorid ephippia declined, the total concentration of cladoceran remains increased (up to almost 2000 individuals per $\mathrm{g}$ of dry sediment), and Bosmina reached its maximum (over $90 \%$ ) in the sample at a depth of $4 \mathrm{~cm}$ (ca. 1985 AD).

TOC varied between 1.8 and $9.6 \%$ with an increasing trend until the present time. The $\mathrm{C} / \mathrm{N}$ ratio ranged between 9.6 and 14.2, indicating that organic matter in the lake consists of a mixture of aquatic and terrestrial plants. The $\delta^{13} \mathrm{C}$ ranged between -29.4 and $-25.8 \%$, and the lowest values were noted after 1985. A similar trend was observed in the $\delta^{15} \mathrm{~N}$ curve (Fig. 5). The negative values of the isotopic curve occurred over the last few decades; during the last two centuries, the values changed within -1.3 to $3.2 \%$.

A total of 111 diatom species belonging to 33 genera were identified in Przedni Staw Polski. In these sediments, considerable changes in the diatom communities occurred during the 1960s. Until the present time (DPSP 1) the lake was dominated by benthic taxa (Sienkiewicz and Gąsiorowski 2014) such as Sellaphora seminulum (Grun.) Mann and Naviculadicta digitulus (Hust.) Lange-Bertalot \& Metzeltin. In zone DPSP 2, rapid alterations were observed in the diatom flora. Based on PCA analysis, the longest trajectory was between 1948 and 1968 (Fig. 4). During this time, dramatic and significant (Table 3) shifts occurred in the diatom community, which may be associated with the lake being restocked several times. The first axis of PCA separates planktonic and tychoplanktonic diatoms on the positive end from benthic species on the negative end. The arrows of planktonic Discostella pseudostelligera (Hust.) Houk and Klee and Fragilaria nanana indicate that these species increase strongly along the first principal component, which lie on the top-right-hand side of the diagram and they are abundant in the last few decades. However, an increase 

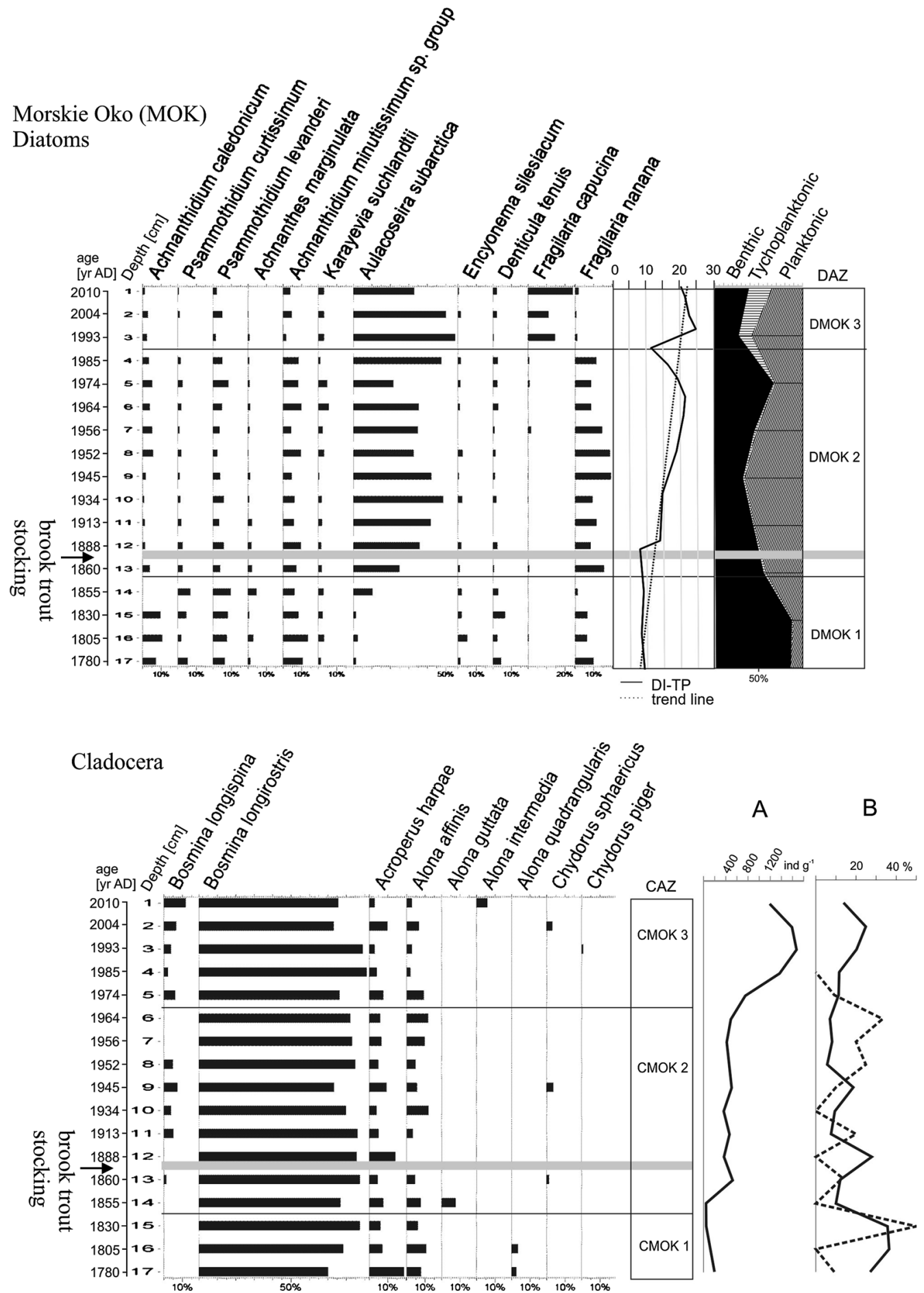

Fig. 3 Stratigraphic abundance of diatoms (species occurring at $>5 \%$ ) and cladoceran taxa of the sediment sequence from Morskie Oko (MOK). The lake has a natural fish population, and additional fish introduction is indicated by grey bars. a number of individuals per $1 \mathrm{~g}$ of dry sediment; $\mathbf{b}$ percentages of bosminid (solid line) and chydorid (dashed line) ephippia. DI$T P$-diatom-inferred total phosphorus 

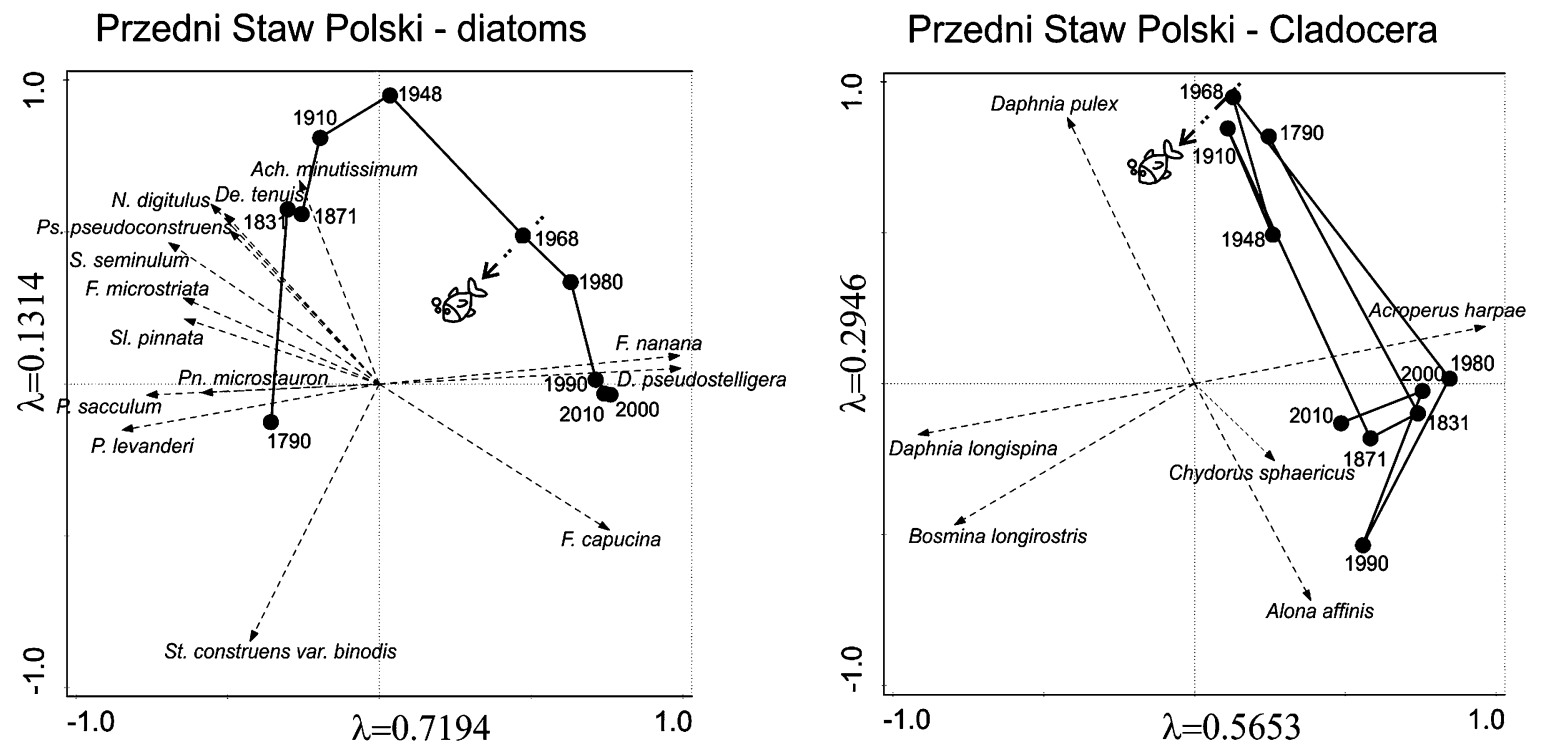

\section{Morskie Oko - diatoms}

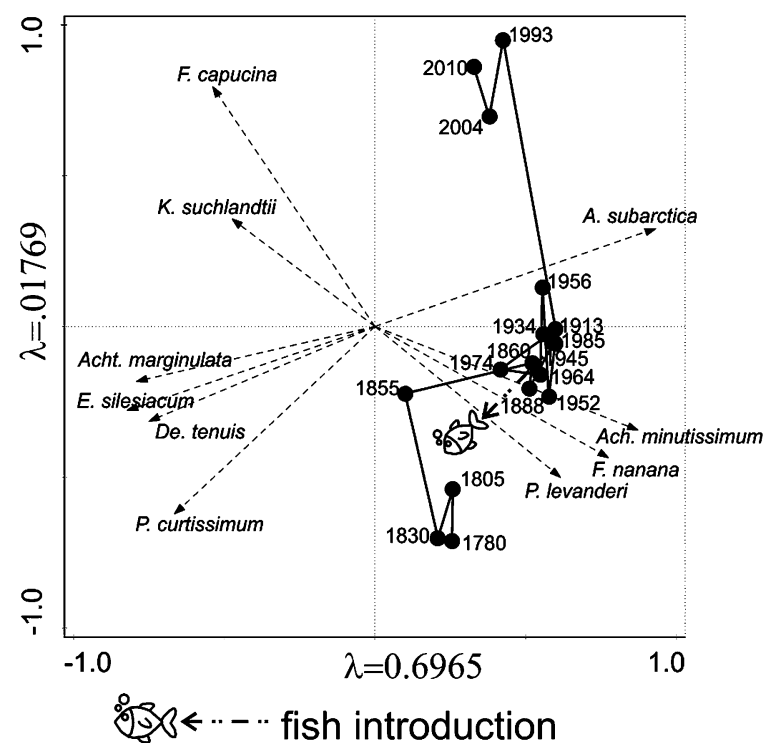

Fig. 4 Principal Components Analysis (PCA) for axes 1 and 2 showing diatom and Cladocera species for lakes with fish. Samples, namely their dating results, are expressed as points and species scores as vectors. Fish introduction or re-stocking was marked on the biplots for Przedni Staw Polski and Morskie Oko.

of tychoplanktonic Fragilaria capucina, which lie on the bottom-right-hand corner of the diagram has occurred later than planktonic taxa. The second axis displays development of benthic taxa (e.g., Psammothidium levanderi (Hust.) Buktyarova \& Round) connected with period before fish introduction.

Abbreviations A Aulacoseira, Ach Achnanthidium, Acht Achnanthes, $D$ Discostella, De Denticula, E Encyonema, $F$ Fragilaria, K Karayevia, N Naviculadicta, P Psammothidium, Pn Pinnularia, Ps Pseudostaurosira, S Sellaphora, Sl Staurosirella, St Staurosira

In Przedni Staw Polski, fish introduction resulted in a severe decrease in benthic taxa, while the frequency of planktonic diatoms, such as Discostella pseudostelligera, Fragilaria nanana and tychoplanktonic $F$. capucina, increased to their maximum abundances in the core. These changes are also presented in Fig. 6 . 

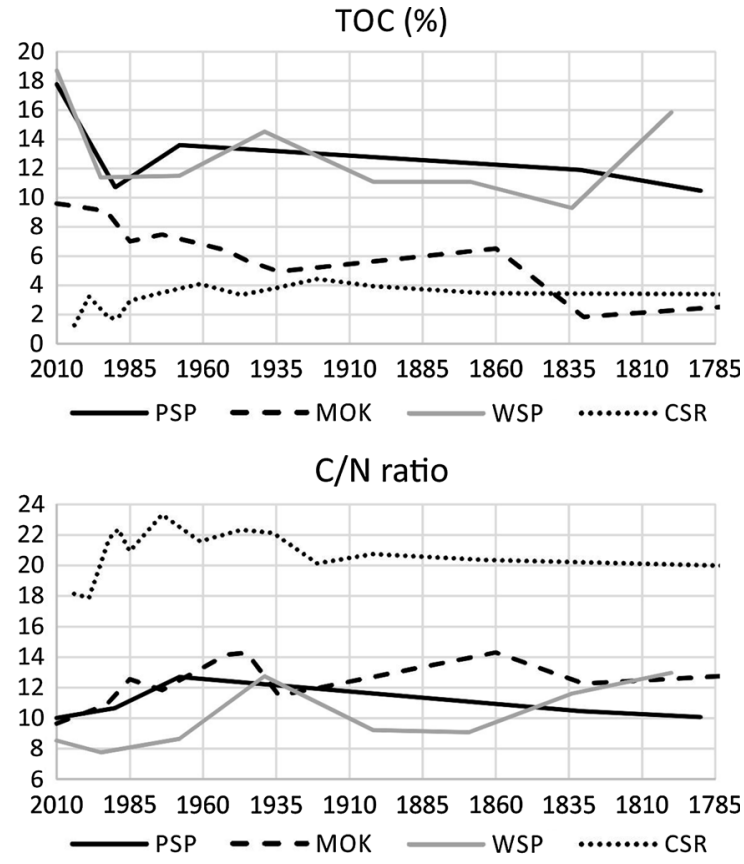

$\delta^{13} \mathrm{C}(\%)$

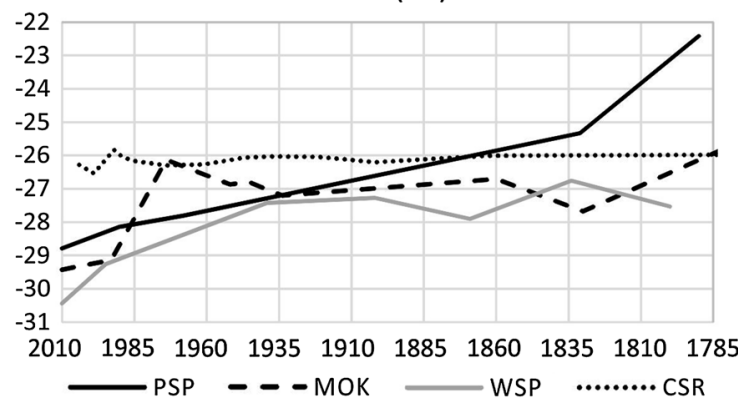

$\delta^{15} \mathrm{~N}(\%)$

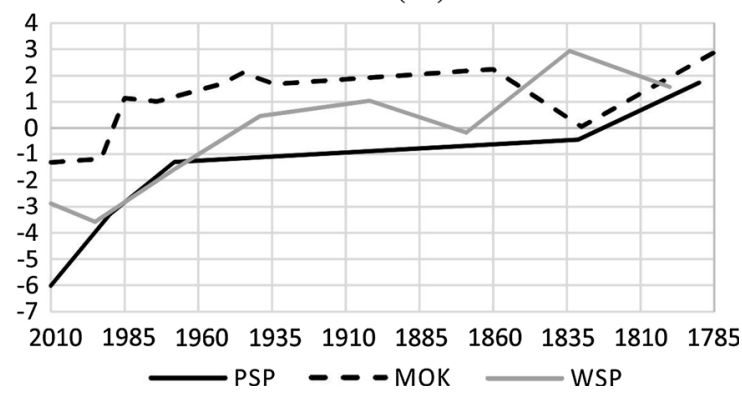

Fig. 5 Total organic carbon (TOC), $\mathrm{C} / \mathrm{N}$ ratio and stable isotope data for Wielki Staw Polski (WSP), Przedni Staw Polski (PSP), Morskie Oko (MOK) and Czarny Staw pod Rysami (CSR)

Reconstructions of total phosphorus varied between 7.1 and $28.3 \mu \mathrm{g} \mathrm{L}^{-1}$. From the early 1970 s to the present, the average value of DI-TP was $\sim 22 \mu \mathrm{g} \mathrm{L}^{-1}$, indicating mesotrophic conditions (Fig. 6).
In total, 7 cladoceran taxa belonging to 3 families were identified from the Przedni Staw Polski core (Fig. 6). Planktonic taxa were represented by Daphnia spp. and Bosmina longirostris. The sediment sequence was divided into 2 cladoceran zones. The first zone (CPSP 1) was characterised by changing percentages of Daphnia spp. Additionally, the total number of remains in $1 \mathrm{~g}$ of dry sediment fluctuated. Benthic taxa were represented by Acroperus harpae, Alona affinis and Chydorus sphaericus. Daphnia completely disappeared in zone CPSP 2 (since the 1970s) and were replaced by Bosmina longirostris in the recent samples. This shift coincided with fish stocking in the lake (Fig. 6). Acroperus harpae and Alona affinis were the most numerous Cladocera. In addition, Chydorus sphaericus increased in the most recent sample.

During approximately the last 200 years, the amount of total organic carbon in the sediments of Przedni Staw Polski ranged from 10.7 to $17.8 \%$, while the $\mathrm{C} / \mathrm{N}$ ratio indicated a mixture of phytoplankton plus terrestrial plants delivered to the lake from the catchment $(\mathrm{C} / \mathrm{N}=10.0-12.7)$. During this time, $\delta^{13} \mathrm{C}$ decreased to just above $6 \%$. The highest value $(-22.4 \%$ o) was noted around $1780 \mathrm{AD}$, while the lowest value $(-28.8 \%$ ) was observed in recent times. A similar trend was observed in the $\delta^{15} \mathrm{~N}$ curve. The values for the nitrogen stable isotope varied between -6.0 and $1.7 \%$; changes in $\delta^{15} \mathrm{~N}$, which took place over a relatively short time since the end of the 1960 s to the present, were substantial and equal to just above $7 \%$ (Fig. 5).

Diatom and cladoceran stratigraphy, isotopic data and quantitative analyses in the sediments of Czarny Staw pod Rysami (CSR) and Wielki Staw Polski (WSP)

In the sediments of Czarny Staw pod Rysami, 136 diatom taxa belonging to 42 genera were identified. The development of the diatom flora over 200 years was generally uneventful (Fig. 7). Zone DCSR 1 is dominated by the benthic Achnanthidium minutissimum species group and the planktonic and eutrophic species Asterionella formosa Hassall. Together, they constitute between 27 and $47 \%$ of all diatom taxa in this interval. Zone DCSR 2 is characterised by the decrease and/or disappearance of some planktonic taxa, e.g., Puncticulata radiosa (Grun.) Håkansson. The PCA plot shows that the arrow of Achnanthidium 

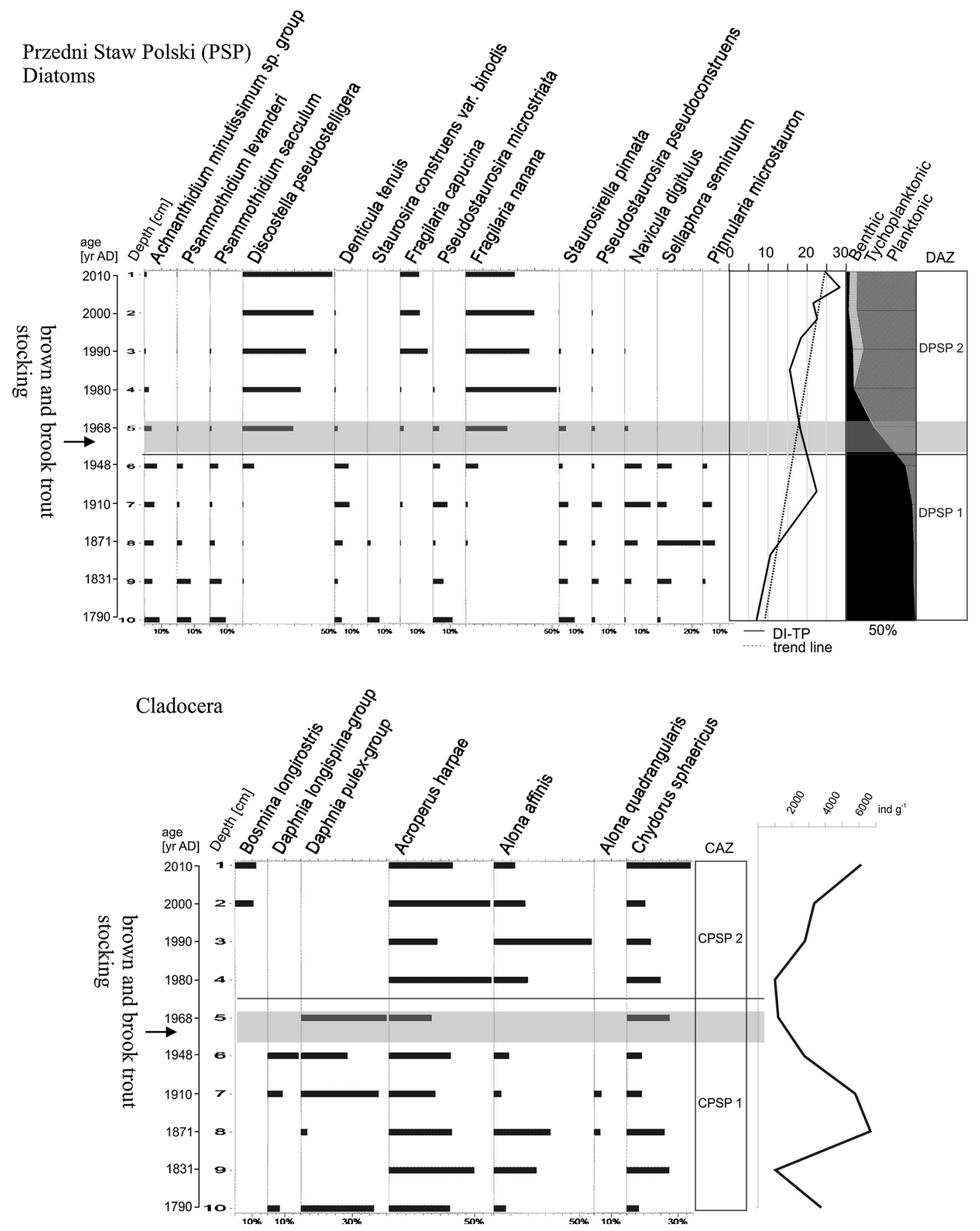

Fig. 6 Stratigraphic abundance of diatoms (species occurring at $>5 \%$ ) and cladoceran taxa in the sediment sequence from Przedni Staw Polski (PSP). The lake was naturally fishless, and

minutissimum points to an increase along PCA axis 1 and high negative correlation with Puncticulata radiosa, which lies on the bottom-left-hand corner of additional fish introduction is indicated by grey bars. DI-TP diatom-inferred total phosphorus

the diagram. The second principal component indicates a gradient from Discostella pseudostelligera to Karayevia suchlandtii (the top-right-hand corner of 

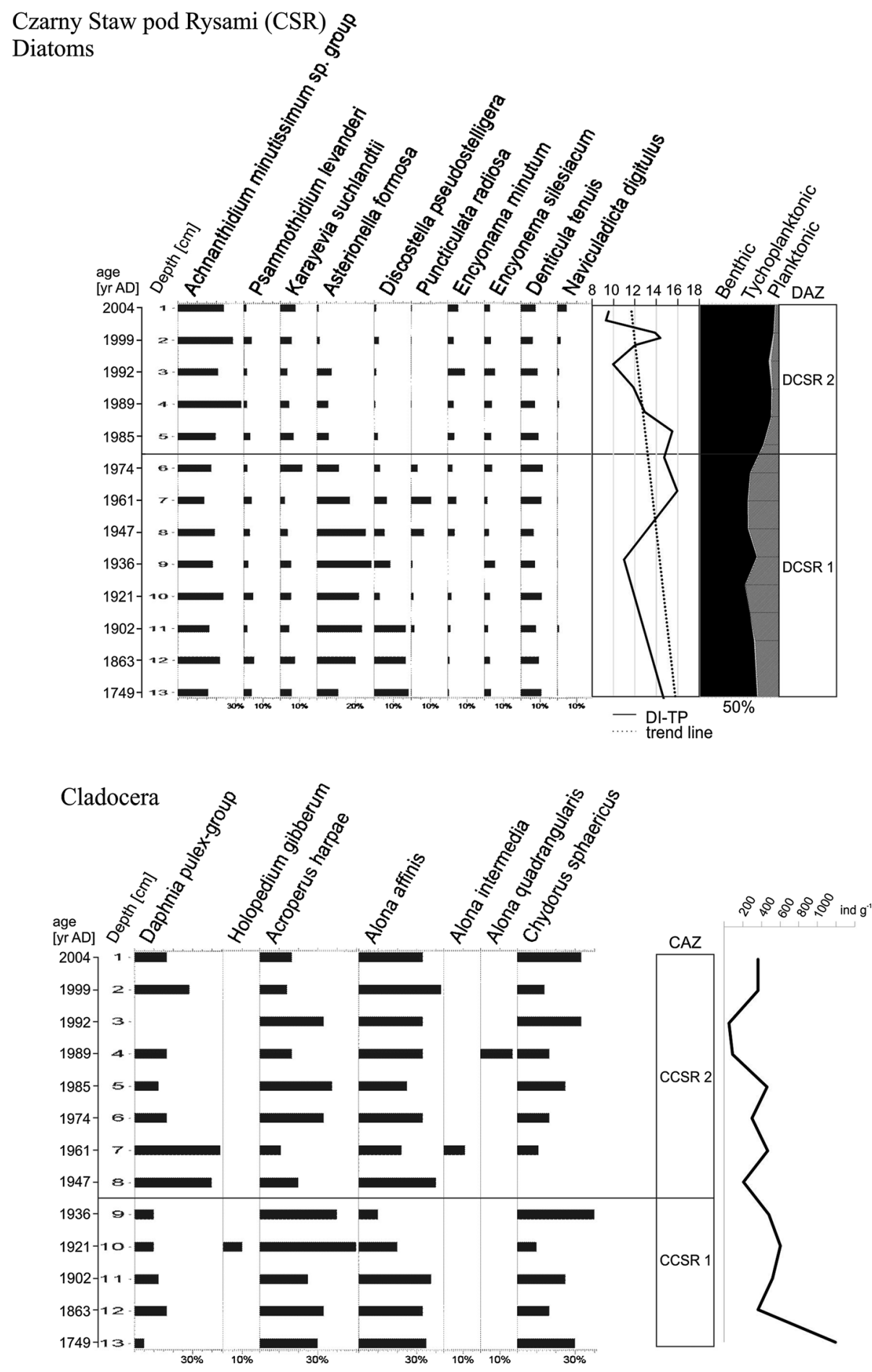

Fig. 7 Stratigraphic abundance of diatoms (species occurring at $>5 \%$ ) and cladoceran taxa in the sediment sequence from Czarny Staw pod Rysami (CSR). The lake is naturally fishless. DI-TP diatom-inferred total phosphorus 
the diagram). The longest trajectory, which is a reflection of the highest changes in diatom assemblages, took place in the 1960 and 1970s. In the last few decades, the relatively short trajectory of diatom sample scores points to stability and minor changes in diatom succession. During the last 200 years, diatominferred total phosphorus varied between 9.3 and $16.3 \mu \mathrm{g} \mathrm{L}^{-1}$, which indicates an oligo-mesotrophic lake (Fig. 7).

The cladoceran assemblage of the Czarny Staw pod Rysami sediment sequence consists of 7 taxa (Fig. 7): the planktonic Daphnia pulex group, Holopedium gibberum, and the benthic chydorids Acroperus harpae, Alona affinis, Alona intermedia, Alona quadrangularis and Chydorus sphaericus. In addition, the absolute number of cladoceran remains was low and varied from only 50 individuals per $\mathrm{g}$ of dry sediment in the sample from horizon $3 \mathrm{~cm}$ dated ca. $1995 \mathrm{AD}$ to almost 1200 individuals $\mathrm{g}^{-1}$ in the sample dated ca. 1749 AD. Two cladoceran zones were described on the basis of changes in species composition. Zone CCSR 1 (13-9 cm, 1749-1936 AD) was characterised by the dominance of benthic taxa. Acroperus harpae was the most abundant species (average relative abundance $35.7 \%$ ) in the upper part of this zone (Fig. 7). In zone CCSR 2 (ca. 1936-2012 AD), the percentages of specific taxa changed and no particular species was dominant, but Daphnia spp. was more abundant than in CCSR 1, especially until the 1970s. As indicated ANOSIM test, the changes in Cladocera assemblage were insignificant (Table 3 ). Due to a very low concentration of cladoceran remains in the sediments, the PCA results for that lake should be interpreted with caution (Fig. 8).

The TOC varied between 1.3 and $4.4 \%$. The $\mathrm{C} / \mathrm{N}$ ratio ranged from 17.9 to 23.3 , with the highest values from the beginning of the twentieth century to the end of the 1990s (Fig. 5). Alterations in values of $\delta^{13} \mathrm{C}$ were small and equal to less than $1 \%$ (from -25.83 to $-26.54 \%$ ). The small amounts of nitrogen in the sediments of Czarny Staw pod Rysami did not permit the determination of $\delta^{15} \mathrm{~N}$.

A total of 157 diatom species belonging to 35 genera were identified from Wielki Staw Polski. The development of the diatom flora followed a rather stable pattern until approximately the end of the 1970s. Up to this period, benthic diatoms such as Achnanthes spp. generally dominated in the lake. However, diatoms associated with deeper mixing depths, e.g., Aulacoseira lirata (Ehr.) Ross, were also found in this part of the core (DWSP 1) (Fig. 8). The diatom ordination by PCA indicates a clear trend in diatom development in the last decades (DWSP 2); an increase in planktonic Fragilaria nanana and Discostella pseudostelligera was noted, but the frequency of benthic taxa decreased. This is confirmed by the trajectory of the taxon sample scores and the stratigraphic distribution of diatoms (Figs. 8, 9). Diatominferred total phosphorus indicates that the lake was oligotrophic until 1985 AD (Fig. 9). From 1985 until the present, a slight increase in DI-TP $\left(11-15 \mu \mathrm{g} \mathrm{L}^{-1}\right)$ has resulted in an oligo-mesotrophic character of the lake.

The subfossil assemblage of Cladocera from Wielki Staw Polski was slightly more diverse than the assemblage in CSR (Fig. 9). Nine cladoceran taxa were identified from the entire sediment sequence, and the total concentration of remains varied from 2100 individuals $\mathrm{g}^{-1}$ (ca. $1852 \mathrm{AD}$ ) to over 8000 individuals $\mathrm{g}^{-1}$ (ca. $1902 \mathrm{AD}$ ). The sediment sequence was divided into two cladoceran zones (CWSP1, CWSP2). The CWSP1 zone (until 1940 AD) was characterised by relatively low percentages of Daphnia (up to $26.1 \%$ ), and the Daphnia longispina group was present only in the lowest part of the sequence. Benthic chydorids were dominated by Acroperus harpae (up to $46.2 \%$ ), with a significant but changing share of Alona affinis (up to $50 \%$ ), Chydorus sphaericus (up to $24.1 \%$ ) and Alona quadrangularis (up to $19.2 \%$ ). The small species Unapertura latens was recorded for the first time in the Tatra Mountains. The CWSP2 zone (from 1940 AD) began with an increase in the Daphnia pulex group. Alona affinis showed strong peak, but other Chydoridae showed non-varying percentages. The Daphnia longispina group remained, but the Daphnia pulex group increased significantly toward the top of the sediment sequence (Fig. 8). In the youngest samples, Alona quadrangularis and small Alona species disappeared, and Acroperus harpae, Alona affinis, and Chydorus sphaericus sensu lato were the only identified benthic taxa of Cladocera.

The TOC ranged from 9.3 to $18.7 \%$, with the highest increase noted from the 1990s to the present. The $\mathrm{C} / \mathrm{N}$ ratio varied between 7.7 and 13.0 and suggests that the source of organic matter was phytoplankton with a small admixture of terrestrial plants. The shifts in $\delta^{13} \mathrm{C}$ ranged between -26.8 and 

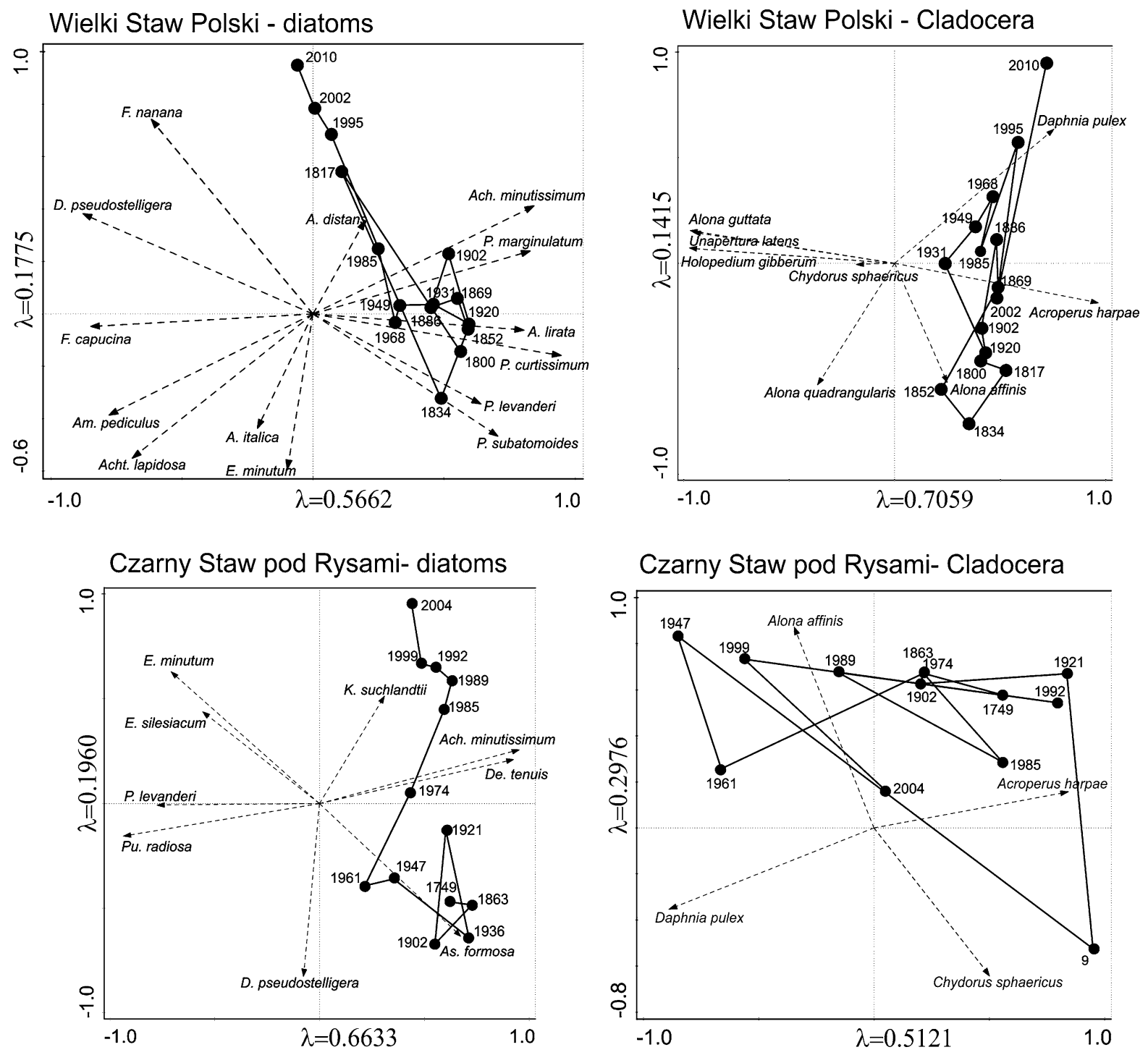

Fig. 8 Principal Components Analysis (PCA) for axes 1 and 2 showing diatom and Cladocera species for fishless lakes (Wielki Staw Polski and Czarny Staw pod Rysami). Samples, namely their dating results, are expressed as points and species scores as

$-30.4 \%$ in the topmost sample, whereas changes in $\delta^{15} \mathrm{~N}$ varied between -3.6 and $2.9 \%$ (Fig. 3).

\section{Discussion}

Planktivorous fish can very effectively change zooplankton communities in oligotrophic alpine lakes (Strock et al. 2013). In our study, the disappearance of large Daphnia was clearly synchronised with the

vectors. Abbreviations A Aulacoseira, Ach Achnanthidium, Acht Achnanthes, As Asterionella, D Discostella, De Denticula, E Encyonema, F Fragilaria, K Karayevia, P Psammothidium, Pu Puncticulata

introduction of fish to Przedni Staw Polski (Figs. 4, 6). Gliwicz and Rowan (1984) reported an absence of Daphnia in the lake in the early 1980s. According to the sediment record, Daphnia disappeared before the early 1980s. Generally, in relatively small and shallow alpine lakes, fish predation results in an effective and rapid reduction in the density of large-bodied Cladocera (Schabetsberger et al. 2009). The other prominent change in the zooplankton community of Przedni Staw Polski was the first occurrence of Bosmina longirostris 

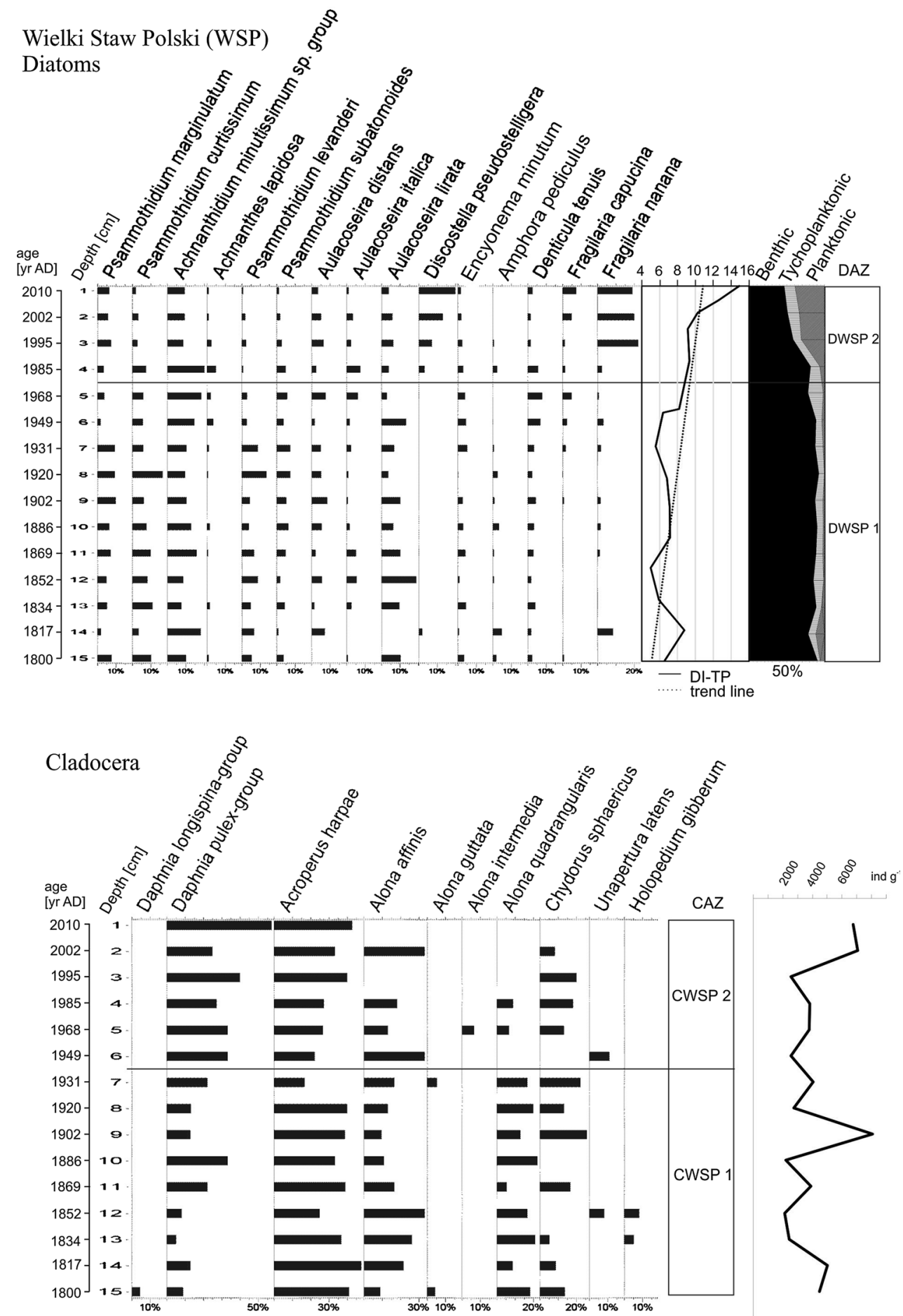

Fig. 9 Stratigraphic abundance of diatoms (species occurring at $>5 \%$ ) and cladoceran taxa of the sediment sequence from Wielki Staw Polski (WSP). The lake is naturally fishless. DI-TP diatom-inferred total phosphorus 
in the sediment in $2000 \mathrm{AD}$ (Fig. 6). This species was absent in the sediment record for at least two millennia, and its presence confirmed eutrophication and/or strong fish predation pressure on large-bodied zooplankton. This pressure created a free niche for small-bodied grazers such as $B$. longirostris. The occurrence of $B$. longirostris in the last decades was not observed in other lakes in the Tatra Mountains, so a regional trend triggered by climate warming ( $\mathrm{Ne}-$ valainen et al. 2014), for example, may be excluded.

Similar to Cladocera, fish stocking in Przedni Staw Polski was also clearly reflected by the phytoplankton in the early 1970s (Table 3). Similar important changes in the diatom flora in response to fish introduction were observed by Drake and Naiman (2000) in Mt. Rainier National Park, Washington. It confirmed that algae are among the first organisms that react to changes in trophic dynamics (Wolfe et al. 2003). The changes in diatom communities observed for this period were probably due to higher nutrient concentrations. A substantial increase (approximately $30 \%$ ) in mesotrophic Fragilaria nanana was noted (Fig. 6), and the frequency of Discostella pseudostelligera, which prefers meso-eutrophic waters (Cremer et al. 2001; Pappas 2010), increased to above $50 \%$ in the youngest sediments. Moreover, an increase in the frequency of $D$. pseudostelligera can also indicate longer ice-free periods linked to twentieth century climate warming and/or more stable thermal stratification (Karst-Riddoch et al. 2005).

The lack of long-term monitoring data concerning the stability of thermal stratification, water/air temperature or ice-free time in the Tatra lakes means that we can only speculate that climate has contributed to changes in the diatom communities. Shifts in phytoand zooplankton can be caused by one driver, for example, by atmospheric pollutants or a combination of common drivers (Pla et al. 2009). The widespread burning of coal and other fossil fuels was crucial for global warming over approximately the past 150 years and is as well documented in the polar regions as in remote lakes located in temperate zones (Clarke et al. 2005; Smol et al. 2005, Pla et al. 2009; Rühland et al. 2013). The effect of these changes is mirrored by an increase in planktonic taxa, especially in the development of Cyclotella spp. The recent success of this species is linked to reduced ice cover and/or strong thermal stratification (Smol et al. 2005). Since the 1960s, considerable changes in $\delta^{13} \mathrm{C}$ and $\delta^{15} \mathrm{~N}$ have been observed in the studied lake sediments (Gạsiorowski and Sienkiewicz 2013) and were interpreted as an input of extra loads of nitrate and sulphur originating from the burning of fossil fuels. The $\delta^{13} \mathrm{C}$ values in Przedni Staw Polski ranged from about -22 to $-25 \%$ in the lower segment of the core but then declined to the lowest value of $-29 \%$ in the surface sediments (Fig. 5).

The trend towards more negative $\delta^{13} \mathrm{C}$ values in surface sediments can be related to the consumption of ${ }^{13} \mathrm{C}$-depleted $\mathrm{CO}_{2}$ formed during the degradation of sinking organic matter by aquatic biota (Vreca and Muri 2006). However, from the 1960s to the present, the magnitude of these changes in $\delta^{13} \mathrm{C}$ was small (approximately $1 \%$ ), and the introduction of fish did not provide a clear signal in the isotopic composition. Decreases in the $\delta^{15} \mathrm{~N}$ value (approximately $5 \%$ ) and the $\mathrm{C} / \mathrm{N}$ ratio (from approximately $13-10$ ) and an increase in TOC concentration together with extra loads of nutrients (DI-TP simultaneously increasing from approximately $12-27 \mu \mathrm{g} \mathrm{L}^{-1}$ ) indicate enhanced aquatic primary productivity and eutrophication (Lin et al. 2006). In lakes where the $\mathrm{C} / \mathrm{N}$ ratios equal approximately 10 , the major source of organic matter is usually assumed to be aquatic plants (i.e., freshwater phytoplankton). $\mathrm{C} / \mathrm{N}$ ratios between 10 and 20 indicate that the organic matter is a mixture of phytoplankton and vascular plants, but if organic matter has $\mathrm{C} / \mathrm{N}$ values greater than 20 , it contains cellulose-rich and protein-poor vascular land plants (Meyers and Teranes 2004).

During these periods, the changes in $\delta^{15} \mathrm{~N}$ varied between -1 and $-6 \%$ in the sediments of Przedni Staw Polski. These values suggest that except for the effect of fish introduction, atmospheric pollution was also mirrored in this isotopic record because $\mathrm{NH}_{3}$ from coal combustion ranges from -10 to $0 \%$ and $\mathrm{NO}_{\mathrm{x}}$ emitted from vehicle exhausts varies between -13 and $-2 \%$, but nitrate and ammonium fertilizers typically have $\delta^{15} \mathrm{~N}$ of -3 to $+3 \%$ (Heaton 1990; Wolfe et al. 2003). Thus, we assumed that the amounts of nitrogen compounds originate from different sources.

We compared the plankton record from Przedni Staw Polski with the cladoceran assemblage from the nearby fishless Wielki Staw Polski. The small-bodied Daphnia longispina group also disappeared in the WSP, but it was not synchronous with the changes in Przedni Staw Polski and occurred as early as the early nineteenth century (Fig. 9). After this disappearance, 
the large-bodied Daphnia pulex group substantial increased.

To our knowledge, fish were never successfully introduced to Wielki Staw Polski (Gliwicz and Rowan 1984). Therefore, we concluded that the decline in small-bodied Daphnia was not related to fish introduction to the lake but rather caused by an increase in lake productivity and stronger food competition from large-bodied grazers. Another possible reason for the Daphnia longispina group decline could be pressure from invertebrate predators, which selectively eliminated smaller zooplankton (Ha and Hanazato 2009). Although WSP is a fishless lake, an increase in trophic status was also observed there. However, the rise in DI-TP in Wielki Staw Polski began approximately 20 years later on a smaller scale (approximately $5 \mu \mathrm{g} \mathrm{L}^{-1}$ ) compared with PSP (Figs. 6, 9). It is possible that Wielki Staw Polski, a much larger lake than Przedni Staw Polski, reacted later to the same load of nutrients per unit of water volume delivered from the catchment area. Changes in TP can be related to the density of catchment vegetation (Kopáček et al. 2000) and tourist activities because a year-round mountain hut exists on the shore of Przedni Staw Polski. Wielki Staw Polski is located a few metres lower than PSP, so during high water levels (e.g., spring melting), the lake can be supplied by the water from PSP and other surrounding ponds. The isotopic composition of the sediments of Wielki Staw Polski may be indirectly linked to processes taking place in Przedni Staw Polski (Gąsiorowski and Sienkiewicz 2013). As a result of intensive tourism, there is an increase in soil erosion around the lake, which delivers allogenic material with nutrient loads from the catchment (Toro and Granados 2002).

A cause-effect relationship also exists between an increase in trophic level and an increase in airborne pollution from NOx deposition. The same deposition process responsible for acidification may result in excessive nutrient concentrations in soil and aquatic bodies and, as a consequence, eutrophication. Inorganic $\mathrm{N}$ is an important nutrient, which, together with phosphorus $(\mathrm{P})$, regulates the growth of phytoplankton. An increase in atmospheric deposition rich in nitrogen can change the balance between limiting nutrients. If lakes were $\mathrm{N}$-limited in their natural state, the rise of atmospheric nitrogen can increase primary productivity and eutrophication (Bergström et al. 2005). Differences in the timing of the beginning of eutrophication in PSP and in WSP were due to the various sizes and morphometries of both lakes and the occurrence of fish in PSP.

The stocking of fish in Morski Oko had a smaller influence on the zooplankton community compared with Przedni Staw Polski (Table 3). Morskie Oko has a natural population of brown trout, which explains the relatively low density of large-bodied Daphnia (Gliwicz et al. 2001; Jeppesen et al. 2003) and the dominance of Bosmina longispina (Fig. 5). The artificially introduced brook trout did not change this state, and even the higher density of fish in the lake did not affect the zooplankton. This finding is in contrast to the situation reported by Jacques et al. (2005), who described a strong influence of cisco (Coregonus artedii Lesueur) on the density of Daphnia and an increase in the relative abundance of Bosmina longirostris. However, brook trout have food preferences similar to those of native brown trout and had no additional influence on zooplankton in MOK. The fish stocking in 1881 was roughly coincident with changes in the total organic carbon and diatom flora (Figs. 3, 5). During that period, eutrophic Aulacoseira subarctica strongly increased in abundance, indicating an increase in the trophic state in Morskie Oko. These alterations were probably related to additional stocking of the lake. However, between the end of the 1960 and $1985 \mathrm{~s}$, a decrease is observed in diatom-inferred total phosphorus. This decline coincided with the establishment of Tatra National Park and a total prohibition in 1968 of cattle grazing in the lake's catchment. A result was the reduction of animal waste rich in nitrogen and phosphorus compounds and soil erosion around the lake. As a consequence, the lake received smaller nutrient inputs from the surrounding watershed compared to the previous period.

The next increase in the trophic state of the lake (DI-TP values, Fig. 3) was observed during the last few decades. Throughout the entire record, these changes were coincident with a gradual increase in total organic carbon and alterations in $\delta^{15} \mathrm{~N}$ (Fig. 3). Presumably, this was an effect of the natural fish population and additional restocking in Morskie Oko. During the last 200 years, $\delta^{15} \mathrm{~N}$ in the sediments of MOK varied between -1.5 and $+3 \%$, while nitrate and ammonium fertilizers generally have $\delta^{15} \mathrm{~N}$ of -3 to $+3 \%$ (Wolfe et al. 2003). A similar eutrophication tendency was not observed in fishless Czarny Staw pod Rysami located in the same valley. There is no 
clear trend in the changes in diatom-inferred TP during the past century. The diatom-inferred TP indicates oligotrophic to slightly mesotrophic water in the lake (Fig. 7). However, the values of DI-TP can be overestimated to some extent because the modern diatom training set used for the reconstruction of TP contains lakes with a long total phosphorus gradient. The small dissimilarities between DI-TP and measurements in the water column may be due to the relatively high mean TP concentration of the calibration set $\left(68 \mu \mathrm{g} \mathrm{L}^{-1}\right)$ (Bennion and Appleby 1999).

The DI-TP values often reflected more than 1 year in the reconstruction model and may not precisely represent a single measurement. However, the trend of these alterations and when and how much a lake has changed throughout the time period are more important issues. The amplitude of the diatom-inferred TP in CSR was only $5 \mu \mathrm{g} \mathrm{L}^{-1}$ during the last two millennia. The lack of an unequivocal tendency in the TP curve suggests that the changes were naturally occurring and not induced by human activity. For instance, the development of diatoms and Cladocera was relatively stable (Fig. 7). The greatest changes in the phyto- and zooplankton communities were noted in the highest part of the core (ca. 1961-2012 AD). During the last 50 years, the number of planktonic diatom taxa decreased substantially. These reductions were mainly in diatoms preferring mesotrophic and eutrophic waters (i.e., Asterionella formosa and Discostella pseudostelligera), while the percentages of planktonic Cladocera belonging to the genus Daphnia increased. These changes could be connected to the smaller input of organic matter and nutrients from the catchment, which was confirmed by TOC analysis, and the decrease in the $\mathrm{C} / \mathrm{N}$ ratio (Fig. 3). The low productivity of the lake can also be related to low water temperature and poor solar radiation (Panzenböck et al. 2000). The relatively high values of the $\mathrm{C} / \mathrm{N}$ ratio show that the main source of carbon was a mix of phytoplankton and terrestrial plant parts (mainly pollen) transported into the lake. However, these values can also be a consequence of very low nitrogen concentrations in the sediments. Fluctuations in $\delta^{13} \mathrm{C}$ in Czarny Staw pod Rysami were relatively small $(\sim 0.7 \%$ ) in the entire sediment sequence, and we concluded that stable environmental conditions existed there for at least two millennia.

\section{Conclusions}

1. Biological proxies and sediment geochemistry, especially total organic carbon and $\delta^{15} \mathrm{~N}$ together with statistical analysis indicate that the highest changes in the studied lakes have occurred in Przedni Staw Polski. Based on the PCA trajectories of diatom and cladoceran sample scores, the most intense alterations occurred in the period of fish introductions.

2. We observed a decline in large-bodied zooplankton immediately after fish stocking in a primary fishless lake and no significant change in a lake with a natural fish population. The disappearance of large-bodied zooplankton caused by increasing and selective fish pressure occurred approximately 10 years after a major fish stocking, which was similar to the timeframe in other alpine lakes.

3. Fish stocking also closely reflected the effects on phytoplankton (i.e., an increase in planktonic diatoms). The main alterations in diatom assemblages were synchronised with the introduction of fish to Przedni Staw Polski and the restocking of Morskie Oko. From that time, diatom-inferred total phosphorus levels indicate a strong increase in the fertility of these lakes. However, shifts in lake ecosystems are also linked to climate change and atmospheric deposition (the rise in planktonic diatoms in the mid-eighties of the twentieth century in fishless Wielki Staw Polski).

4. Changes in trophic status were also caused by catchment vegetation and tourist activity. However, the development of communities in fishless Czarny Staw pod Rysami and Wielki Staw Polski during the last decades has proceeded in a more balanced manner and without a clear trend of TP changes. A slight increase in trophic level (to oligo-mesotrophy) was observed only in Wielki Staw Polski during recent years.

Acknowledgments We thank two anonymous reviewers for their helpful comments to improve the manuscript. We are also grateful to Agata Pruszczyńska, Magda Radzikowska, Michał Radzikowski and Wojtek Sienkiewicz for their efforts during the winter coring campaigns. We are also grateful to the authorities and employees of Tatra National Park for their help and assistance during the field work. The investigations were financially supported by the Polish National Centre of Science (Grant No. N N306 077436). 
Open Access This article is distributed under the terms of the Creative Commons Attribution 4.0 International License (http:// creativecommons.org/licenses/by/4.0/), which permits unrestricted use, distribution, and reproduction in any medium, provided you give appropriate credit to the original author(s) and the source, provide a link to the Creative Commons license, and indicate if changes were made.

\section{References}

Battarbee RW (1986) Diatom analysis. In: Berglund BE (ed) Handbook of holocene palaeoecology and palaeohydrology. Willey, Newyork, pp 527-570

Bennion H, Appleby PG (1999) An assessment of recent environmental change in Llangorse Lake using palaeolimnology. Aquat Conserv 9:361-375

Bergström A-K, Blomqvist P, Jansson M (2005) Effects of atmospheric nitrogen deposition on nutrient limitation and phytoplankton biomass in unproductive Swedish lakes. Limnol Oceanogr 50:987-994

Birks HJB, Line JM, Juggins J, Stevenson AC, ter Braak CJF (1990) Diatoms and pH reconstruction. Philos T R Soc B 327:263-278

Carpenter SR, Kitchell JF (1993) The trophic cascade in lakes. Cambridge University Press, Cambridge, p 399

Carpenter SR, Christensen DL, Cole JJ, Cottingham KL, He X, Hodgson JR, Kitchell JF, Knight SE, Pace ML (1995) Biological control of eutrophication in lakes. Environ Sci Technol 29:784-786

Clarke KR (1993) Non-parametric multivariate analysis of changes in community structure. Aust J Ecol 18:117-143

Clarke G, Kernan M, Marchetto A, Sorvari S, Catalan J (2005) Using diatoms to assess geographical patterns of change in high-altitude European lakes from pre-industrial times to the present day. Aquat Sci 67:224-236

Cremer HB, Wagner M, Melles M, Hubberten H-W (2001) The postglacial environmental development of Raffles Sø, East Greenland: inferences from a 10,000 year diatom record. J Paleolimnol 26:67-87

Drake DC, Naiman RJ (2000) An evaluation of restoration efforts in fishless lakes stocked with exotic trout. Conserv Biol 14:1807-1820

Gąsiorowski M, Sienkiewicz E (2010) 20th century acidification and warming as recorded in two alpine lakes in the Tatra Mountains (South Poland, Europe). Sci Total Environ 408:1091-1101

Gąsiorowski M, Sienkiewicz E (2013) The sources of carbon and nitrogen in mountain lakes and the role in human activity in their modification determined by tracking stable isotope composition. Water Air Soil Poll 224:1498

Gliwicz MZ, Rowan MG (1984) Survival of Cyclops abyssorum tatricus (Copepoda, Crustacea) in alpine lakes stocked with planktivorous fish. Limnol Oceanogr 29:1290-1299

Gliwicz ZM, Ślusarczyk A, Ślusarczyk M (2001) Life history synchronization in a long-lifespan single-cohort Daphnia population in a fishless alpine lake. Oecologia 128: 368-378
Gordon AD, Birks HJB (1972) Numerical methods in palaeoecology. I Zonation of pollen diagrams. New Phytologist 71:961-979

Goslar T, Pazdur MF (1989) Improved precision ${ }^{14} \mathrm{C}$ measurements and natural $14 \mathrm{C}$ variations around $10,000 \mathrm{cal} \mathrm{BP}$. Radiocarbon 31:833-838

Ha JY, Hanazato T (2009) Role of interference from Daphnia and predation by cyclopoid copepods in zooplankton community structure: experimental analysis using mesocosms. Plankton Benthos Res 4:147-153

Hammer $\varnothing$, Harper DAT, Ryan PD (2001) PAST: paleontological statistics package for education and data analysis. Palaeontol Electron 4:1-9

Heaton THE (1990) ${ }^{15} \mathrm{~N} /{ }^{14} \mathrm{~N}$ ratios of NOx from vehicle engines and coal-fired power station. Tellus 24B:304-307

Hercman H, Pawlak J (2012) MOD-AGE: an age-depth model construction algorithm. Quat Geochronol 12:1-10

Hercman H, Gąsiorowski M, Pawlak J (2014) Testing the MODAGE chronologies of lake sediment sequences dated by the $\mathrm{Pb}-210$ method. Quat Geochronol 22:155-162

Hořická Z, Stuchlík E, Hudec I, Černý M, Fott J (2006) Acidification and the structure of crustacean zooplankton in mountain lakes: the Tatra mountains (Slovakia, Poland). Biologia 61(Suppl. 18):S121-S134

Jeppesen E, Jensen JP, Lauridsen TL, Amsinck SL, Christoffersen K, Søndergaard M, Mitchell SF (2003) Sub-fossdils of cladocerans in the surface sediment of 135 lakes as proxies for community structure of zooplankton, fish abundance and lake temperature. Hydrobiologia 491:321330

Juggins S (1992) TRAN (Version 1.8) and ZONE (Version 1.2) User Manual

Juggins S (2001) The European diatom database, user guide, Version 1.0

Karst-Riddoch TL, Pisaric MFJ, Smol JP (2005) Diatom responses to 20th century climate-related environmental changes in high-elevation mountain lakes of the northern Canadian Cordillera. J Paleolimnol 33:265-282

Katsaounos CZ, Giokas LD, Leonardos ID, Karayannis MI (2007) Speciation of phosphorus fractionation in river sediments by explanatory data analysis. Water Res 41:406-418

Kopáček J, Stuchlík E, Straškrabová V, Pšenáková P (2000) Factors governing nutrient status of mountain lakes in the Tatra Mountains. Freshw Biol 43:369-383

Kopáček J, Stuchlík E, Hardekopf D (2006) Chemical composition of the Tatra Mountains lakes: recovery from acidification. Biologia 61(Suppl. 18):S21-S33

Kownacki A (2004) Branchinecta palludosa (O.F. Müller, 1788). In: Głowaciński Z, Nowacki J (eds) Polish Red Data Book of Animals-Invertebrates. IOP PAN - Kraków, AR-Poznań. pp 35-36

Krammer K, Lange-Bertalot H (1986) Süßwasserflora von Mitteleuropa. Bacillariophyceae. I. Teil: Naviculaceae.Gustav Fisher Verlag, Stuttgart, Germany: 1-876

Krammer K, Lange-Bertalot H (1988) Süßwasserflora von Mitteleuropa Bacillariophyceae. 2. Teil: Bacillariaceae, Epithemiaceae, Surirellaceae.Gustav Fisher Verlag, Stuttgart, Germany: 1-596Krammer K, Lange-Bertalot H (1991a) Süßwasserflora von Mitteleuropa. Bacillariophyceae. 3. 
Teil: Centrales, Fragilariaceae, Eunotiaceae.Gustav Fisher Verlag, Stuttgart, Germany, pp 1-576

Krammer K, Lange-Bertalot H (1991b) Süßwasserflora von Mitteleuropa. Bacillariophyceae. 4. Teil: Achnanthaceae, Kritische Ergäzungen zu Navicula (Lineolatae) und Gomphonema Gesamtliteraturverzeichnis Teil 1-4. Gustav Fisher Verlag, Stuttgart, Germany. pp 1-437

Lange-Bertalot Metzeltin D (1996) Ecology-diversity-taxonomy. Indicators of oligotrophy -800 taxa representative of three ecologically distinct lake types. In: Lange-Bertalot $\mathrm{H}$ (ed) IconographiaDiatomologica 2. Koeltz Scientific Books, Koenigstein, pp 1-390

Lin L, Wu J, Wang S (2006) Evidence from isotopic geochemistry as an indicator of eutrophication of Meiliang Bay in Lake Taihu, China. Sci China Ser D Earth Sci 46(Suppl 1):62-71

Makos M, Nitychoruk J, Zreda M (2012) The Younger Dryas climatic conditions in the Za Mnichem Valley (Polish High Tatra Mountains) based on exposure-age dating and glacier-climate modelling. Boreas 42:745-761

Meyers PA (1997) Organic geochemical proxies of paleogeographic, paleolimnologic, and paleoclimatic processes. Org Geochem 27:213-250

Meyers PA, Laillier-Vergès E (1999) Lacustrine sedimentary organic matter records of late quaternary paleoclimates. J Paleolimnol 21:345-372

Meyers PA, Teranes JL (2004) Sediment organic matter. In: Last WM, Smol JP (eds), Tracking environmental change using lake sediments. 2: 239-269

Nevalainen L, Ketola M, Korosi JB, Manca M, Kurmayer R, Koinig KA, Psenner R, Luoto TP (2014) Zooplankton (Cladocera) species turnover and long-term decline of Daphnia in two high mountain lakes in the Austrian Alps. Hydrobiologia 722:75-91

Panzenböck M, Möbes-Hansen B, Albert R, Herndl GJ (2000) Dynamics of phyto- and bacterioplankton in a high Arctic lake on Franz Joseph Land archipelago. Aquat Microb Ecol 21:265-273

Pappas JL (2010) Phytoplankton assemblages, environmental influences and trophic status using canonical correspondence analysis, fuzzy relations, and linguistic translation. Ecol Inform 5:79-88

Pla S, Monteith D, Flower R, Rose N (2009) The recent palaeolimnology of a remote Scottish loch with special reference to the relative impacts of regional warming and atmospheric contamination. Freshw Biol 54:505-523

Ramsey CB (2009) Bayesian analysis of radiocarbon dates. Radiocarbon 51:337-360

Reimer PJ, Bard E, Bayliss A, Beck JW, Blackwell PG, Ramsey CB, Buck CE, Cheng H, Edwards RL, Friedrich M, Grootes PM, Guilderson TP, Haflidison H, Hajdas I, Hatté C, Heaton T, Hoffmann DL, Hogg A, Hughen KA, Kaiser K, Kromer B, Manning SW, Niu M, Reimer R, Richards DA, Scott EM, Southon JR, Staff RA, Turney C \& Plicht J (2013) 'IntCal13 AND Marine13 radiocarbon age calibration curves $0-50,000$ years cal BP'. Radiocarbon. pp 1869-1887

Roozen FCJM, Lürling M, Vlek H, Van Der Pouw Kraan EAJ, Ibelings BW, Scheffer M (2007) Resuspension of algal cells by benthivorous fish boots phytoplankton biomass and alters community structure in shallow lakes. Freshw Biol 52:977-987

Rühland KM, Paterson AM, Keller W, Michelutti N, Smol JP (2013) Global warming triggers the loss of a key Arctic refugium. Proc R Soc B 280:20131887

Sarmaja-Korjonen K (2003) Chydorid ephippia as indicators of environmental change biostratigraphical evidence from two lakes in southern Finland. Holocene 13:691-700

Schabetsberger R, Luger MS, Drozdowski G, Jagsch A (2009) Only the small survive: monitoring long-term changes in the zooplankton community of an Alpine lake after fish introduction. Biol Invasions 11:1335-1345

Schindler DE, Knapp RP, Leavitt PR (2001) Alteration of nutrient cycles and algal production resulting from fish introductions into mountain lakes. Ecosystems 4:308-321

Sienkiewicz E, Gąsiorowski M (2014) Changes in the trophic status of three mountain lakes in southern Poland-natural or anthropogenic process? Pol J Environ Stud 23:875-892

Ślusarczyk M (1997) Impact of fish predation on a small-bodied cladoceran: limitation or stimulation? Hydrobiologia 34:215-221

Smol JP, Wolfe AP, Birks HJB, Douglas MSV, Jones VJ, Korhola A, Pienitz R, Rühland K, Sorvari S, Antoniades D, Brooks SJ, Fallu M-A, Hughes M, Keatley BE, Laing TE, Michelutti N, Nazarova L, Nyman M, Paterson AM, Perren B, Quinlan R, Rautio M, Saulnier-Talbot E, Siitonen S, Solovieva N, Weckström J (2005) Climate-driven regime shifts in the biological communities of arctic lakes. Proc Nat Acad Sci USA 102(12):4397-4402

Sønderaard M, Jensen JP, Jeppensen E (2003) Role of sediment and internal loading of phosphorus in shallow lakes. Hydrobiologia 506-509:135-145

St Jacques J-M, Douglas MVS, Price N, Drakulic N, Gubala CP (2005) The effect of fish introductions on the diatom and cladoceran communities of Lake Opeongo, Ontario, Canada. Hydrobiologia 549:99-113

Strock KE, Saros JE, Simon KS, McGowan S, Kinnison MT (2013) Cascading effects of generalist fish introduction in oligotrophic lakes. Hydrobiologia 711:99-113

Stuchík E, Kopáček J, Fott J, Hoŕická Z (2006) Chemical composition of the Tatra Mountains lakes: response to acidification. Biologia 61(Supp. 18):S11-S20

Szeroczyńska K, Sarmaja-Korjonen K (2007) Atlas of subfossil Cladocera from central and northern Europe. Friends of the Lower Vistula Society, Poland

Temporetti PF, Pedrozo FL (2000) Phosphorus release rates from freshwater sediments affected by fish farming. Aquac Res 31:447-455

ter Braak CJF, Šmilauer P (2012) Canoco reference manual and user's guide: software of ordination (version 5.0). Microcomputer Power (Ithaca, NY, USA), p 496

Tiberti R, von Hardenberg A, Bogliani G (2014) Ecological impact of introduced fish in high altitude lakes: a case of study from the European Alps. Hydrobiologia 724:1-19

Tolotti M (2001) Phytoplankton and littoral epilithic diatoms in high mountain lakes in the Adamello-Brenta Regional Park (Trentino, Italy) and their relation to trophic status and acidification risk. J Limnol 60:171-188

Toro M, Granados I (2002) Restoration of a small high mountain lake after recent tourist impact: the importance of 
limnological monitoring and paleolimnology. Water Air Soil Poll Focus 2:295

Vreca P, Muri G (2006) Changes in accumulation of organic matter and stable carbon and nitrogen isotopes in sediments of two Slovenian mountain lakes (Lake Ledvica and Lake Planina) induced by eutrophication changes. Limnol Oceanogr 51:781-790
Witkowski A (1996). Fish. In: Mire Z (ed) Nature of the Tatra National Park. Tatrzański Park Narodowy, in Polish, pp 485-492

Wolfe AP, Van Gorp AC, Baron JS (2003) Recent ecological and biogeochemical changes in alpine lakes of Rocky Mountain National Park (Colorado, USA): a response to anthropogenic nitrogen deposition. Geobiology 1:153-168 